\title{
STSEENILISE OLEVIKU MÕJUJÕUST KIRJANDUSLIKU REALISMI ESTEETIKAS
}

\author{
INDREK OJAM, JAAK TOMBERG
}

\section{Sissejuhatus}

$\mathrm{K}$ irjandusteaduslikes aruteludes realismi üle on juba mõnda aega eristatud realismi mõiste kaht tähendustasandit: kitsamal tasandil peetakse realismi all silmas esmajoones XIX sajandi ajaloolist kirjandusvoolu, laiemal tasandil aga universaalset ja ajaloolistest raamidest sõltumatut kunstilist meetodit.

Essees „Realism kirjandusuurimises” käsitleb René Wellek realismi kitsamal tasandil, püüdes määratleda seda kui periodiseerivat mõistet. Ta demonstreerib üksikasjalikult, kuidas juba XIX sajandi teise poole ja XX sajandi alguse dispuutides oli „realismi” tähendusväli ja kasutusulatus traditsiooniti väga erinev - prantsuse, vene, inglise, saksa, itaalia ja ameerika kirjandusruumis ei tähendanud realism tingimata üht ja sedasama asja ega olnud ka oma mõjujõult kultuuripildis ühevõrra kesksel positsioonil (Wellek 1976: 226232; edaspidi sulgudes ainult leheküljenumber). Wellek näitab, et nendes aruteludes käsitleti realismiga seonduvalt üldjoontes hõlpsasti tuvastatavat hulka põhiatribuute ja raskuspunkte: realismi kui poleemilist relva romantismi fantastilisuse, muinasjutulisuse, sümboolsuse ja allegoorilisuse vastu (lk 241); realismi ja naturalismi erinevust (lk 233-235); kirjelduse ja ettekirjutuse vahelist pingevälja (lk 242); realistlikku „tegelastüüpi”, mis peaks kehastama ja leevendama universaalse ja partikulaarse vastuolu (lk 245); objektiivsust kui „umbusku... romantilise egojoovastuse vastu” ja kui „impersonaalsust, autori täielikku puudumist teosest” (lk 247 jj); nõuet, et realism oleks „ajalooline”, et inimest kujutataks kui osakest totaalsest poliitilisest, sotsiaalsest ja majanduslikust reaalsusest, mis on konkreetne ja pidevalt arenev (lk 251). Ent samal ajal demonstreerib Wellek kogu essee vältel ka seda, kuidas eri traditsioonide eri autorid ei olnud nende atribuutide täpse tähendussisu ja rolli suhtes kaugeltki ühel nõul. Tema kokkuvõtva sedastuse järgi tuleb realismi kui periodiseeriva mõiste määratlemisel paratamatult piirduda „rahutukstegevalt triviaalse” määratlusega (lk 252). Realism on „kaasaegse sotsiaalse tegelikkuse objektiivne representatsioon" (lk 240-241, 253; fraas juba originaalis jutumärkides), ning seda üksnes tingimusel, et realismi käsitletaks esmajoones kui „regulatiivset ideed, ideaalset tüüpi, millele ei pruugi täielikult vastata ükski üksikteos” (lk 252).

Seevastu laiemal, universaalse kunstilise meetodi tasandil on realismi määratletud võttena, mis taotleb võimalikult maksimaalse tõetruudusega tegelikkuse edasiandmist (Jakobson 2014: 36). Seda taotlust toestab kõige üldisemal, epistemoloogilisel tasandil veendumus või usk, mida realist enamasti ei vaidlusta: et väljaspool sõnu eksisteerivad asjad ja väljaspool teksti eksisteerib tegelikkus; et sõnu ja asju, teksti ja tekstivälist maailma saab 
vastavusse seada; ning et see vastavus saab olla vähem või rohkem „tõetruu” ja erapooletu, objektiivne. Ühest hiljutisest akadeemilisest koondkogumikust „Seiklused realismis” („Adventures in Realism”, 2007), mis käsitleb põhjalikult realismi eri avaldumisvorme, suhteid teiste kujutamisviisidega ning eri teoreetilisi tõlgendusvõtmeid, võime leida mitu sellesuunalist üldist tõdemust: realismi „eesmärgiks on tegelikkuse või „elu” õige esitamine” (Bowlby 2007: xvi); realism „pühendab end järjekindlalt ühele raskele tööle: püüule jõuda sõnade juurest asjade juurde, nii nagu need on" (Levine 2007: 16); realismi võib „lühidalt visandada kui eeldust, et representatsiooni kaudu on võimalik ühes või teises semiootilises koodis tagada nii tunnetuslik kui ka kujutlusvõimeline ligipääs materiaalsele ja ajaloolisele tegelikkusele, mida vahendavad küll taandamatult inimteadvus ja keel, ent mis eksisteerib neist sellegipoolest eraldi" (Beaumont 2007: 2).

Võiks väita, et niimoodi mõistetuna läbistab „püüd realismi suunas” punase niidikesena ka XIX sajandi klassikalisele perioodile järgnenud kirjandusvoolusid - realism kitsamas mõttes kujutab endast vaid esimest etappi sõnade ja asjade tõepärasesse vastavusse viimise püüu pikemas ajaloolises järgnevuses (vt Bowlby 2007: xvi). ${ }^{1}$

Sõltumata tasandist ning peaaegu truistlikult enesestmõistetavast asjaolust, et igas teoses on vormitud kindlale autorile omaseid „subjektiivseid” kogemusi, paistab niisiis just realismiga käivat kaasas oluline, kuid esmapilgul hämaravõitu tunnetuslik nõue: igatsus realismi järele on soov tunda ära midagi „objektiivset”. Teisisõnu, kirjandusliku realismi tunnetuslik objekt tundub teiste kanooniliste voolude, kas või sümbolismi või sürrealismi omaga võrreldes olevat kuidagi intuitiivselt lihtsamini kokku lepitav. Meil oleks alati justkui ähmane arusaam, et ootame realismilt peale kunstilise elamuse ka mingisugust spetsiifilist ühist äratundmist.

Käesolevas artiklis käsitleme üht teoreetiliselt veel vähe sõnastatud välja, mis realistlikule kirjandusele sellise mõjujõu võiks tagada ning millelt kõnealuse ühise äratundmise universaalsus muuhulgas lähtuda võiks. Selleks väljaks on eelkõige XIX sajandi realismist alates tuntuks saanud materiaalsete nähtuste ning nende üksikasjade detailsed kirjeldused, mille ajaloolist esilekerkimist kirjanduses jõustas kaheldamatult historistlikust ajalooteadvusest kantud ja loodusteaduslikes taksonoomiates väljenduv ajastu vaim. Mahukaid kirjeldavaid lõike võib kindlasti pidada klassikaliste realistlike ja naturalistlike kirjandusteoste kompositsiooni silmapaistvaks pärisosaks: üldtuntud näidetest esimesena meenuvad proua Vaquer' pansioni põhjalik kirjeldus

${ }^{1}$ Nende tasandite taga luurab realismi kolmas ja veel laiem, filosoofilis-epistemoloogiline tasand. Simon Dentith märgib tabavalt, et viimasel piirjoonel on realism ,igasuguse kirjutuse pelk epistemoloogiline mõõde [---], sest kõik lausungid (ja realistlikud romaanid koosnevad vähemalt lausungitest) leiavad aset ühises materiaalses ja sotsiaalses maailmas, millest väljaspool poleks neil tähendust - selles mõttes on „realism” vahend osutamaks nende lausungite möödapääsmatule pragmaatilisele asukohale. Sama kehtib nii nendes žanrides, mis ületavad igapäevase usutavuse ja tõenäolisuse kaanoneid, kui ka žanrides, mis nendest kaanonitest kiivalt kinni peavad, kuna kõik lausungid saavad oma tähenduse selle kaudu, kuidas nad asetuvad maailma, mida asustavad rääkija ja kuulaja, kirjutaja ja lugeja" (Dentith 2007: 33-34). See tasand on aga liiga üldine, et kirjanduse uurimisel heuristilist väärtust evida. Märksa kasulikuma, realismi mõiste loomulikku ajaloolist arengut kaardistava kolmeastmelise skeemi visandab Jaan Undusk Friedebert Tuglase kriitilist tegevust käsitlevas monograafias (vt Undusk 1986, eriti lk 8-17). 
Balzaci „Isa Goriot's” (millest tuleb lähemalt juttu ka siinse artikli neljandas peatükis) või Charles Bovary mannetu ja ebakombeka mütsi kirjeldus Gustave Flaubert'i „Madame Bovary” alguses. Selliste ja sellelaadsete kirjelduste kompositsioonilist funktsiooni kirjandusliku realismi üldises esteetikas on juba küllaldase põhjalikkusega analüüsitud (vt nt Lukács 2005, 2006: 17-46; Sutškov 1984). Meie siinseks eesmärgiks on aga selle kirjeldusliku välja sidumine realismile omistatava representatsioonilise „objektiivsusega”. Küsime: millisel spetsiifilisel viisil võiksid kirjeldused panustada realismi objekti ühisesse äratuntavusse? Võttes aluseks Roland Barthes'i tuntud tõdemuse, et realistlik tõepärasus (realismi „objektiivsus”) põhineb sündmustiku seisukohalt ebaolulistel detailidel (Barthes 2002), püüame hiljutiste realismiteooriate toel näidata, et kirjelduste vald kannab klassikalises realismis ja naturalismis suures osas hoolt inimeste kultuurilise eksistentsi kehalise, meelelise ja afektiivse ühiskogemuse eest.

Selle eesmärgini jõudmiseks vaatleme kõigepealt teises peatükis Madis Kõivu esseed „Subjektiivsuse objektiivsusest”, mille mitmed ki rja n d u s lik $\mathrm{ku}$ kirjutamisse puutuvad inspireerivad sõnastused seovad kirjutuse objektiivsuse originaalsel viisil puhtfenomenoloogilise eksistentsiga. Kõivu essee on meie arutluse funktsionaalseks lähtepunktiks, aga mitte keskseks uurimisobjektiks. Ehkki Kõiv vastandub oma kirjutusmeetodit iseloomustades klassikalise realismi konventsioonikesksele „objektiivsusele”, võimaldavad tema sõnastused ja järeldused täiendavalt mõtestada Fredric Jamesoni hiljutist, impersonaalse afekti ja isikliku saatuse tasakaalule ehitatud realismiteooriat, mida tutvustame põhjalikumalt kolmandas peatükis. Neljandas peatükis vaatleme mõningaid XIX sajandi prantsuse klassikalisele realismile ja naturalismile omaseid kirjeldusnäiteid ning viime läbi Kõivu ja Jamesoni mõtete sünteesi. Näitame, kuidas Kõivu fenomenoloogilised mõtisklused objektiivsusest ühilduvad Jamesoni nägemusega realistlikest kirjeldustest kui keha impersonaalset eksistentsi markeerivast st s e e nilis e st ol evikust. Arutlust jäävad lõpetama kaks lühemat peatükki, mille funktsioon on nüansseerida eelöeldut ning teha mõned lisajäreldused. Viiendas peatükis näitame, et sõltumata substantsiaalsest „teoreetilisest” ühisosast avaldub stseeniline olevik XIX sajandi realistlikes kirjeldustes ning Kõivu enese prosaistipraktikas peaaegu ühildamatult erineval moel: kui esimesed toetuvad tugevalt diskursiivsetele konventsioonidele, siis viimase kirjanduslikuks agendaks on pageda nende konventsioonide eest puhtfenomenoloogilisse tegelikkusesse. Väljajuhatuses lahkume ajaloolise realismi kitsamalt tasandilt ja osutame ühele võimalusele, kuidas Kõivu ja Jamesoni teooriate süntees, nägemus stseenilise oleviku objektiivsusest, võiks täiendada kirjandusteaduses klassikalist tõenäolisuse mõistet. Seeläbi selgitame, kuidas algselt ajaloolise realismi stseenilise olevikuga seonduv tõepära toestab olulise komponendina ka hilisemate modernistlike kirjandusvormide esteetilist mõjujõudu. 


\section{Madis Kõiv objektiivsest ja subjektiivsest kirjutajast}

Ajakirja Looming 2007. aasta 8. numbris avaldas Madis Kõiv rubriigis „Mõtteid ja märkmeid”2 kaheleheküljelise kirjutise „Subjektiivsuse objektiivsusest”, milles selgitas üht väidetavalt tema loomingu retseptsioonis levinud arusaama. Nimelt olevat Kõiv eesti kirjanduse üks subjektiivsemaid kirjanikke, ehk isegi kõige subjektiivsem. ${ }^{3}$ Kõiv pöörab aga selles väites sisalduvate mõistete tähendused iseäralikul viisil ümber: asjaolu, et tema ei kirjuta „ajastu poolt peale pandud mallides" (Kõiv 2007: 1256), ei tähenda, et tema tegevuses kirjutajana - kui seda õigesti mõista - ei leiduks midagi objektiivset. Ajastule omase malli all mõtleb Kõiv tõenäoliselt nn peavoolu, kirjandusliku kujutamisviisi ligikaudset „keskmist”, mingisugust rohkemal või vähemal määral äratuntavat konventsiooni. Siinkohal on tähenduslik, et Kõiv ei piirdu järgnevas mõne loogiliselt ja filosoofiliselt range subjektiivsuse ja objektiivsuse kontseptuaalse käsitlusega, vaid keskendub ilukirjanduse representatsioonijõu raskesti piiritletavale küsimusele ja haarab oma arutlusse kaasa realismi mõiste, tuues näideteks Eduard Vilde loomingu ja August Gailiti romaani „Ekke Moor”:

Võtame näiteks nn. realistliku proosa. Olgu see kas või Eduard Vilde „Külmale maale” (või mõni muu selletaoline „Ekke Moorini” välja ja kaugemale veel). Üteldakse sel puhul, et romaan kirjeldab objektiivselt oma objekti.... - vaesuse tõttu vargapoisiks muutunud peategelase käekäiku (Kõiv 2007: 1256).

Seoses nende teostega (mis, kui kasutada Kõivu eespool kasutatud sõnu, võiksid olla vähemasti ühele kindlale eesti kultuuri ajastule omase malli esindajad) tõstatab Kõiv intrigeeriva probleemi: mis on ikkagi sellise realistliku romaani objekt? Ning annab ka omapoolse vastuse: „Ajajärgu ja ümbruse murede, meelsuse, meeleolu, nägemuste, hoiakute, hirmude ja armude, keeldude ja käskude poolt kujundatud „reaalsus”. Miski, mida ajajärk ja ümbrus reaalsusena võtta lubab” (Kõiv 2007: 1256). See reaalsus kui ajaja kohavaimude ühislooming on „aja-subjektiivne”, ning tõelise objektiivsuseambitsiooniga kirjutajal on luba seda subjektiivselt vormida. Nii jõuab Kõiv oma mõttekäigu seletamisel definitsioonide juurest pigem kirjutamise meetodi kirjeldamise juurde ja formuleerib oma intuitsiooni, pöörates ootamatult ümber tema retseptsioonis leviva keskse aimuse: kui ta oleks tõeline subjektivist, oleks ta hoopis objektivist. Kõivu arusaamises - ja selline kirjeldus vastab tõepoolest hästi tema enese proosakeele poeetilisele toimele - viib just nimelt

\footnotetext{
${ }^{2}$ Rubriik „Mõtteid ja märkmeid” ei kanna Loomingus alati samasugust pealkirja, kuid on läbi aastate sisaldanud end juba kultuurimaastikul sisse töötanud ja tõestanud autorite spontaansemaid mõtisklusi. Kõivu kirjatükk, millest siinkohal analüüsime vaid kirjandusliku realismi kohta käivat osa, on mitmes mõttes omapärane. Seda võib lugeda kui nn vastust kriitikutele, oma loomingu seletust, eneseanalüüsikatset või iseseisvat filosoofilist lühiarutlust.

${ }^{3}$ Kõiv ei viita sealjuures konkreetsetele nimedele ega tekstidele. Ühe niisuguse määratluse Kõivu kui filosoofi ja esseisti keelekasutusele annab Aare Pilv „Luhta-mineku” järelsõnas: „...üks Kõivu mõtlemise eripära ongi see, et ta ei välju individuaalsusest õieti kunagi. Ja just hoidumatus eneseküllasest subjektiivsusest annab tulemuseks midagi pisut paradoksaalset - Kõivu filosoofiline mõte (niivõrd kui seda saab filosoofiliseks pidada) on oma solipsismist hoolimata väga „kõnekas”, dialoogiline” (Pilv 2005: 668-669, aga vt ka Rähesoo 1999: 1863-1864, 2000: 1365).
} 
radikaalne subjektiivsus ja maksimaalne oma minasse süvenemine välja tõelise objektiivsuseni, niivõrd kui sellest sõnast belletristika kontekstis rääkida saab. Objektiivsus selles ümberpööratud mõttes tähendab jõudmist „mina” juurest „meieni”:

Ainult süvenedes oma mina põhjani, kuni ta osutub millekski, mida võime nimetada „meieks” - suhteliselt (belletristika piir! siinpool ei saa miski olla absoluutselt absoluutne) absoluutseks meieks või ühisminaks -, võib kirjeldatud subjektiivsuse ületada (Kõiv 2007: 1256).

\section{Selle liikumise kaudu on Kõivu järgi võimalik jõuda momendini, mil}

...langevad ära kõik „minu isiklikud” atribuudid - asjad ja asjaolud. Täpsemalt „mina” enda poolt suvaliselt juhitud ja indutseeritud seigad. Seigad on kaotanud subjektiivse, või kui soovite, siis isikliku värvingu. Seigad tulevad ise, nii nagu nad tulevad, vabad „meie” personaalsest interpreteeringust (Kõiv 2007: 1257).

Sellele järgneb ümberpööramise tulemusena Kõivu samavõrra kompaktselt sõnastatud objektiivsusekäsitlus:

Asjade isetulemine on süvenemises sündinud absoluutse meie ühiskogemus, selles mõttes objektiivne, ja ainult see ühiskogemus saabki sel (metafüüsikast äralõigatud) belletristlikul tasemel olla objektiivne, siin, sel tasemel edasi (kõrgemale? sügavamale?) minna ei saa - per definitionem juba - belletristika mõiste määrab selle piiri (Kõiv 2007: 1257). ${ }^{4}$

Kuigi Kõivu lühitekst on täis pidevaid kõhklusi, pehmendusi ja täpsustusi, eriti belletristika ja metafüüsika segaste suhete osas, loeme s õ na-sõ nalt just neid keskseid kohti seikadest, mis „on kaotanud subjektiivse.... värvingu” ja „tulevad ise...., vabad „meie” personaalsest interpreteeringust” ning võtame tõsiselt nende formuleeringute võimalikku tähendust nii realismi kui ka tegelikult kogu kirjanduse representatsioonivõime jaoks. Siinkohal on otsustav, kuidas mõista absoluutset meiet või ühismina, millele arutluse all olev objektiivsusepretensioon toetub. Ehkki tundub, et Kõiv kirjeldab selles arutluses oma loomingu eripära ning vastandab selle teatud lihtsustatud arusaamale realistlikust kirjandusest, evivad äratoodud sõnastused mõtestavat potentsiaali ka klassikalistes realistlikes tekstides prominentsete igapäevaeluliste kirjelduste jaoks. Veel enam, Kõivu enesegi esialgu hämaravõitu keskne intuitsioon täpsustub ja täieneb, kui asetada see dialoogi uuemate realismiteooriate, eelkõige Fredric Jamesoni kirjutatuga.

${ }^{4}$ Kõiv püsib sellega filosoofilises raamistuses, millel on äratuntavalt kantiaanlikud juured. Kanti järgi eristub esteetiline otsustus (ja ühtlasi otsustus kõigi sõnakunstiteostes leiduvate representatsioonide kohta) loogilisest, objektiga seotud otsustusest, mis on teaduse pärusmaa. Kuigi samuti universa alne, on esteetiline otsustus singula a rne, st seda ei tehta juba valmisoleva mõiste pinnalt. Universaalsuse tagab sellele mitte ilusa või üleva kui erilise predikaadi loogiline seostumine objektiga, vaid selle universaalne ühtivus kõigi hindajate meelesättumusega, mis moodustabki Kõivu sõnakasutuses meie (vt Kant 2000: 99-101). 


\section{Fredric Jamesoni realismikäsitlus: jutustus ja stseen, emotsioon ja afekt}

1968. aastal avaldatud loengus „Reaalse efekt” (e.k 2002) juhtis Roland Barthes Gustave Flaubert'i ja ajaloolase Jules Michelet' loomingus ${ }^{5}$ leiduvate näidete abil tähelepanu olulisele tekstuaalsele suundumusele, mis on eriti omane realismile, kuid läbib kogu moodsat kirjandust laiemalt. Jutustusest hakkavad üha jõulisemalt esile tõusma kirjeldavad detailid, mis ei panusta enam kuidagi loo funktsionaalsesse struktuuri, mõjudes selle suhtes „luksusliku”, tähendusetu ülejäägina (Barthes 2002: 106-108). Vaatame lähemalt Flaubert'i näidet. Jutustuse „Üks lihtne hing” alguses kirjeldatakse teenijanna Félicité emandale, proua Aubainile kuuluvat maja:

See kivivooderdisega maja asus põiktänava ja väikese tänava vahel, mis viis jõe äärde. Eri tasapinnad hoone sisemuses põhjustasid komistamist. Kitsas eeskoda eraldas kööki „saalist”, kus proua Aubain veetis kogu pika päeva akna all korvtoolis istudes. Valge krohvseina ääres oli reas kaheksa mahagonipuust tooli. Vana klaver baromeetri all kandis püramiidi meenutavat pappkarbi- ja kartongikuhja (Flaubert 1995: 11).

Selle väljatõste viimast lauset tsiteerides tõstab Barthes esile baromeetri kui detaili, mis erinevalt teistest enam loo seisukohalt midagi ei tähenda (püramiidi meenutaval kartongikuhjal on veel võime konnotatiivselt viidata korratusele ja niimoodi iseloomustada Aubini kodu atmosfääri; vt Barthes 2002: 106-107). ${ }^{6}$ Kuid tsiteeritud lõigust võiks näiteid tuua veelgi: milleks mainida $\mathrm{k}$ aheksat mahagonipuust tooli? Igale Flaubert'i jutustuse lõppu jõudnule on ilmselt selge, et ka sel detailil pole kogu loo kulgemise dünaamika seisukohalt mingisugust märgilist tähendust. Selgub, et esmapilgul luksusliku detaili eesmärk ongi teistsugune. Need kohad, mis mõjuvad jutustamise sündmusliku dünaamika suhtes justkui üleliigsetena, hakkavad Barthes'i sõnul sellistena tähistama „reaalse kategooriat” ennast: „...Flaubert'i baromeeter ja Michelet' väike uks ei ütle lõppude lõpuks muud kui et: meie olemegi „reaal$n e "$ "(Barthes 2002: 116). Märgilise tähenduse, loo suhtes tähendusliku funktsiooni puudumisel saavad neist märkidest reaalsuse pelga olemasolu ning lõpuks realistliku vastavussuhte enese tähistajad, sünnitades nõnda uue, klassikalisele vastanduva realistliku tõepärasuse (Barthes 2002:

${ }^{5}$ Barthes'i lähenemise semiootiline vaatepunkt laseb tal Flaubert'i ja Michelet' tekste probleemideta koos vaadelda, kuna keskmes on narratiivi funktsioneerimise analüüs, mille poeetilised efektid (sh „reaalse efekt” ise) toimivad historiograafias põhimõtteliselt samamoodi kui ilukirjanduses.

${ }^{6}$ Tähte närides võib iga niisuguse detaili võimaliku (mitte)funktsionaalsuse - ning seega ka Barthes'i mõtte - kallal kahtlemata norida: näiteks võib baromeeter panustada majapidamise miljöölisse kirjeldusse ühelt poolt kui osutus emotsionaalsele ebastabiilsusele („soojem”, „külmem”) ning teiselt poolt, vastupidi, kui osutus soovile majapidamist korrastada („mõõta”, „kontrollida”). On selge, et selliste detailide täpne funktsionaalsusaste loo suhtes on igas lugemiskogemuses suuresti nii lugeja isikliku häälestuse kui ka sattumuse küsimus: piisava sihiliku mõttetöö tulemusena võib igale üksikasjale funktsiooni omistada, või vastupidi, iga detail võib loo seisukohalt funktsionaalne olla, ilma et lugeja seda teadvustaks. Sellegipoolest põhistab Barthes'i väidet tõenäosus, et igas konkreetses lugemiskogemuses on erinevad üksikasjad erineva funktsionaalse tähendusastmega. Täname selle tähelepaneku eest Arne Merilaid. 
115-116). ${ }^{7}$ Realismi mõju võib Barthes’i järgi mõista niisiis loo suhtes iseseisvate, sellest eraldunud kildude toimena (lk 115-116).

Niisugusel vastandusel - märgiliselt tähenduslikud detailid $v s$. tähendusetud, näiliselt ebafunktsionaalsed ja „luksuslikud” tegelikkuse markerid - põhineva mõjumudeli hõlmavaks kirjeldamiseks on kindlasti suurima töö teinud Fredric Jameson raamatus „Realismi antinoomiad” (2013). Jamesoni teoreetiline rõhuasetus võrreldes Barthes'iga on romaani kahel erineval ajadimensioonil; selle mõistmine osutub hõlpsamaks, kui resümeerida alustuseks autoripoolset üldisemat, realismi mõiste ajaloolist käsitlust. Juba oma uurimuse sissejuhatuses - ning see oluline eeldus jääb kogu arutlust pidevalt saatma - kirjeldab Jameson realismi kui uurimisobjekti olemuslikku põhiprobleemi: see ei püsi süstemaatilisel vaatlusel kunagi ühtsena silme ees, tuues endaga kaasa kõikvõimalikud binaarsed opositsioonid, mis realismi ideed viirastuslikult saadavad. Nii räägitakse realismi ja sellega koos ühtlasi ro ma a ni kui uusajale olemusliku žanri väljakujunemisest või selle järkjärgulisest lahustumisest XX sajandi modernistlikes vooludes; realismist vastandatuna romantismile, sümbolismile, naturalismile või sotsialistlikule realismile; realismist kui kriitilisest tööriistast ühiskondlike probleemide avamisel vastandatuna arusaamale realismi ühiskondlikku status quo'd kinnitavast iseloomust (Jameson 2013: 1-2). Samamoodi kutsub realismi kasutamine kirjandusloo üht epohhi kirjeldava mõistena ellu erinevad implitsiitsed ajaloonarratiivid, mis peaksid sellele ümbritsevat tuge pakkuma. Nii asetatakse realism ühelt poolt suhtesse sellele eelneva varase valgustusajaga ning viimane omakorda sellele eelneva klassikalise, fikseeritud žanrite ajastuga, mil kõrge ja madal stiil olid veel selgelt lahus hoitud. Teiselt poolt fikseeritakse realismi lõpp selle suubumise või hajumisena modernismi, ning viimase lõpp omakorda üleminekuna postmodernismi (Jameson 2013: 2-3).

Nende teoreetiliste poleemikatega on lahutamatult seotud kaks ajalisuse dimensiooni, mis kogu realismi poeetikat alal hoiavad. Esimene neist on

${ }^{7}$ Barthes'i klassikalise ja „uue” tõepära eristuse saab seada selgituslikku vastavusse prantsuse filosoofi Jacques Rancière’i eristusega „kaunite kunstide” representatiivse režiimi ning kunsti esteetilise režiimi vahel (vt lähemalt Kangro 2012: 131-133). Rancière seab üldisemalt realismi tuleku ning kitsamalt Flaubert'i „Madame Bovary” selleks kirjanduslooliseks tähiseks, millest edasi murenesid otsustavalt vanemate, n-ö „kaunite kunstide” ajastu ranged hierarhiad - kirjandusse puutuvalt näiteks „tegevuse esmasus tegelase suhtes, jutustamise esmasus kirjeldamise suhtes, žanride hierarhia vastavalt nende ainese väärikusele ja kõne, kõnelemise aktuaalsuse esmasus ning kõikide nende elementide analoogia hierarhilise nägemusega kogukonnast" (Rancière 2004: 22). Rancière’i järgi hakkas seda režiimi XIX sajandi keskpaigas järk-järgult asendama kunsti esteetiline režiim, mida määratles hierarhilisuse asemel demokraatia: „kõikide sõnade võrdsustumine, väärikate ja ebaväärikate teemade, jutustamise ja kirjeldamise, esiplaani ja tagaplaani, inimeste ja asjade vahelise hierarhia allasurumine” (Rancière 2011: 8). Rancière’i jaoks märgib ,asjade ja olevuste realistlik paljunemine" (Rancière 2011: 39) selle terviku hävingut, mis oli harmoonias sotsiaalse kehandi varasema stabiilsusega, ning see häving avaldus ühtlasi tolle sotsiaalse hierarhiaga rangelt seotud poeetilise proportsiooni lagunemises. Barthes'ilikult võiks öelda, et just siis ilmusid kirjandusse „luksuslikud”, „tähendusetu ülejäägina” mõjuvad detailid: kangelase traagilise saatuse või õuedaami hapravõitu hingeelu portreteerimise kõrvale kerkis näiteks mütsilodude, aadrilaskmise, koogikeste ja kerjamise harjumuspäratu üksikasjalik kirjelduslasu, mis oli suures kontrastis varasemate, suhteliselt puhastatud ja õhuliste tekstiruumidega, kus valitses range kirjelduslik parajus. Rancière ütleb, et kriitikute jaoks oli Flaubert sellise ajastu kirjanik, kus kõik asjad asuvad samal tasandil ning kus seega ka kõike tuleb kirjeldada(Rancière 2011: 39). 
jutustu s või lug u, ${ }^{8}$ mis koosneb lineaarse aja teljel paiknevatest sündmustest. Intuitiivselt igasuguse proosakirjanduse tuumkomponendina tähendab lugu juba lõpetatud sündmuste esitamist. Loo kuulumine juba-juhtunu valda tähendab kõige vastuolulise allutamist sõnale, asjaolude paika panemist. Nõnda võib öelda, et lugu muundab pelga indiviidi t e g e la s e ks, st kellekski oma isikliku ajaloo ning selgelt määratletud kohaga sümboolsete suhete võrgustikus. Selles mõttes võib loo valla filosoofiliseks sisuks nimetada s a a t u s t (Jameson 2013: 21) - loo struktuurseks sisuks on kangelas(t)e personaalse saatuse teostumine mineviku-oleviku-tuleviku teljel.

Lineaarse aja teljel jutustatava saatuseloo vastandpooluseks realismis on momendid, mil loo jutustamine peatub ja rõhk liigub tekstis sageli esinevatele kirjeldusmassiividele, millel puudub loo suhtes näiliselt funktsioon. Kui Barthes juhtis tähelepanu, et moodsas realistlikus kirjanduses on neil momentidel üha enam kalduvus osutada kõikvõimalikele jutustuse seisukohalt ebarelevantsetele objektidele, siis Jameson täiendab, et see teine diskursusetüüp juhatab ka teise ajarežiimi, mida võiks nimetada keha impersonaalsel olevikul põhinevaks puhtaks stseeniks. Stseeni vald erineb loost kvalitatiivselt ja olemuslikult ning märgime etteruttavalt, et just see erinevus võimaldab Kõivu kirjeldatud „,minu isiklike” atribuutide äralangemise” ja „asjade isetulemise” valguses hiljem mõista, millest tuleneb realistlike kirjelduste intuitiivselt adutav „objektiivsus” ehk realismi objekti suhteliselt hõlpsam kokkulepitavus.

Nimelt sisaldab Jamesoni teooria otsustavat metafüüsilist eristust, mis seob realistliku teksti stseenilise valla mõju puhta teadvuse sfääriga, eraldades viimase omakorda igasugustest personaalsetest identiteetidest, mis jäävad sellele vastandatud jutustuse või loo valda (Jameson 2013: 24-25). Puhta teadvuse sfääris ringlevad kehalised "tundmused" on aga afektiivsed ja im per s o n a ls ed, panevad nimetamisele vastu ning jäävad personaalsesse identiteeti funktsionaalselt panustavate atribuutide suhtes autonoomseks. Tuues teooriasse afekti mõiste, vastandabki Jameson selle nimetatud e motsioonide kategooriale, mis funktsioneerib jutustuse osana:

... sest ma soovin emotsiooni ümber defineerida „nimetatud emotsiooniks” ning märkida seeläbi mitte ainult struktuurset erinevust emotsiooni ja afekti vahel, vaid rõhutada ka selle probleemi üht lisamõõdet, mis puudutab keele kui niisuguse sekkumist. Uueks järelduseks oleks, et afekt (või afektid mitmuses) panevad mingil moel vastu keelele ning selle võimele nimetada asju (ja tundeid), samas kui emotsioon on nähtus, mida artikuleeritakse peaasjalikult nimede reastamise kaudu (Jameson 2013: 29).

Niimoodi piiritletakse afekti üsna vastuolulise mõiste tähendus viisil, mis võimaldab seletada igasuguse keelelise representatsiooni ja kirjanduse ajaloo küsimusi. Kui emotsioonide kategooria (mis on pärandunud meile eri antiikja varauusaegsete süstemaatiliste käsitluste kaudu) on olemuselt teadvustatud ja struktuurne ning liigendub rea nimede kaudu (rõõm, kurbus, kahetsus jne), siis afekt oma püsimatus paljususes on raskesti tabatav, ei ühildu ühegi nimega ja moodustab väljaspool tähendusi eksisteeriva autonoomse

\footnotetext{
${ }^{8}$ Jameson eelistab oma teooriale tunnetuslikult kõige lähedasemana prantsuskeelset sõna récit, jättes selle enamikul kasutuskordadest inglise keelde tõlkimata.
} 
sfääri (Jameson 2013: 29). Sõna „eksisteerima” olevikulisus ja neutraalsus on arutluse selles punktis otsustavad. Kui tavamõistuse ja ühtlasi tavakeele järgi seostub teadvus loomulikul viisil isedusega, nt küsimuses „kas sa ikka teadvustad, mis su ümber toimub?", siis Jamesoni poststrukturalistlikus raamistuses sõnastatud tees viib teadvuse ja identiteedi tasandi määravalt lahku. Peaksime teadvust mõistma hoopis täielikult impersonaalse ja olevikulise taandamisena kehale, mille suhtes kõikvõimalikud nimed, kategooriad ja identiteedid on objektid:

Tahan väita, et teadvuse olevik on mingil moel impersonaalne, et teadvus kui niisugune on impersonaalne; samas kui selle teadvuse subjekt ehk ise on tavamõistes personaalse identiteedi asupaik. Too isedus ise on aga oleviku impersonaalse teadvuse jaoks üksnes objekt ning teatud mõttes eristuvad kõik mineviku-oleviku-tuleviku tasandi personaalsed samastumised impersonaalsest olevikust; kui tahes lahutamatud nad sellest olevikust ka poleks, on nad ikkagi üksnes objektid selle oleviku sees. [---] Nimelt saab selgeks, et mineviku-oleviku-tuleviku, personaalsete identiteetide ja saatuste režiim kujutab endast viimasel piirjoonel jutustamise valda; samas kui igavese või eksistentsiaalse oleviku impersonaalne teadvus valdab viimasel piirjoonel puhast stseeni, näitamist, mis on jutustamisest ülepea lahutatud, eraldatud ja puhastatud (Jameson 2013: 24-25).

Jamesoni põhijäreldus on, et realismi tuleks mõista eelkõige lähtuvalt nende kahe ajapooluse dünaamilisest tasakaalust: kui teksti pinge ühe pooluse kas jutustuse või stseeni, nimetatud emotsiooni või afekti, saatuse lineaarse aja või keha impersonaalse oleviku - kasuks lahendada, kaob ka klassikalisele realismile ainuomane efekt. Iga realistlik tekst hoiab tasakaalu jutustuse ja selle suhtes autonoomsete stseenide vahel.

\section{Stseenilisuse kasvav autonoomia: naturalism kui realismi metodoloogiline ülepingutus}

Et mõista, kuidas jutustuse ja stseeni ajad tekstis vahelduvad ning kuidas kirjelduse üksikasjad võivad narratiivi edasiviimise teenistusest kanduda vahetult kohalviibiva „reaalse efekti” tekitamise teenistusse, tasub klassikaliste näidete varal analüüsida nende erinevat staatust realistlikus ja naturalistlikus kirjelduses. Meie näiteks on meeleliste (peamiselt lõhnade ja valguste) kirjelduste erinev autonoomia Balzaci ja Zola teostes. ${ }^{9}$ Balzac kirjeldab „Isa Goriot'” alguses põhjalikult proua Vaquer' pansioni ja selle ruume. Ühe toa kohta võime lugeda:

${ }^{9}$ Ehkki Jameson käsitleb naturalismi kui erijuhtu realismi laiemas paradigmas, on selge, et naturalism (kas või Zola näitel) märgib ajaloolist momenti, mil jutustuse ja stseeni realistlik tasakaal hakkab juba järk-järgult stseenilisuse poole kaldu vajuma. Metodoloogilises plaanis pole üllatav, et võrdlusliku võtme tolle tasakaalu ilmestamiseks pakub retrospektiivselt moment, mil too tasakaal on ajalooliselt peaaegu ületatud. Naturalism (ning impressionism kui selle „helge” ekvivalent maalikunstis) kujutab endast selles mõttes otsekui vormilist lävepakku realismi ja modernismi vahel (viimases valitseb stseeniline olevik juba märksa täielikumalt). 
Sellest esimesest ruumist hoovab hõngu, millele keel ei ole leidnud nime ja mida peaks hüütama pansionihõnguks. See lehkab umbuse, hallituse, kopituse järgi; see tekitab külmavärinat, tundub niiskena ninas, jääb rõivaste külge, maitseb toa järgi, kus on söödud, tast hoovab köögi, toidukambri, seegi haisu (Balzac 2004: 10-11).

See esmapilgul vägagi meeleline kirjeldus ei esinda siiski puhta stseeni valda, milles kirjeldatava maailma kohta võiks kõivulikult väita, et selle seigad on vabanenud personaalsetest värvingutest. Vastupidi, Balzac hoiab jõuliselt kõiki detaile oma jutustuse funktsionaalses haardes: tugevalt hinnangulistena, on need meelelised detailid ka tähenduslikud, andes Vaquer' pansionile Balzaci põimuvate lugude universumis sümboolse koha. Ehkki autor räägib „hõngust, millele keel ei ole leidnud nime”, oskab ta kohe pärast seda väga hästi nimetada emotsioone, mida „pansionihõng” tekitab, ning neid emotsioone tähenduslikult oma jutustusse lõimida:

Kõik, mis Balzacil paistab füüsilise aistinguna - liisunud lehk, kopitanud maitse, rasvane riie -, tähendab alati midagi, see on mõne tegelase moraalse või ühiskondliku staatuse: väärika vaesuse, räpasuse, tõusikute ambitsiooni, vana aristokraatia tõelise hingesuuruse märk või allegooria. Lühidalt - see pole õigupoolest enam aisting, vaid juba tähendus, allegooria (Jameson 2013: 33).

Erinevalt Balzacist, kes oma kirjelduses püüdleb „pansionihõngu” kui millegi „tüüpilise” tähendusliku sisustamise poole, on Émile Zola looming tulvil näidetest, milles maailma meelelised kvaliteedid on asetunud juba põhimõtteliselt uut moodi kokkuseadesse. Romaanis „Pariisi kõht” jõuab koloniaalmaalt sunnitöölt põgenenud Florent näljast nõrkenuna Pariisi. Saades küüti ühelt juurviljavankrilt, satub Florent varahommikusele Keskturule, kuhu saabuvad kaubavoorid. Põgenev mees tutvub seal kunstnik Claude'iga ja autor kirjeldab turulettidel lebavaid köögivilju:

See oli meri, mis ulatus Saint-Eustache'i ristmiku juurest Keskturu tänavani, kahe paviljonidekobara vahel. Ja kahes otsas, kahel ristmikul suurenes vool ikka veel, köögiviljad lausa matsid enda alla sillutise. Päev tõusis aeglaselt väga mahedas hallis, ujutades kõik asjad üle heleda akvarellivarjundiga. Need säbrulised kuhjad otsekui kiired vood, see tänava suletuses voolav rohelusejõgi, sarnane sügisvihmade hävinguga, omandasid peene ja pärlendava varjundi: õrn lilla, piimvalgega nüansseeritud roosa, kollasesse uppunud rohelised, kõik need kahvatud toonid, mis teevad taevast päikesetõusul helkleva siidi. Peasalatid, lehtsalatid, salatsigurid, sigurid, avali ja veel mullast ligased, näitasid oma säravaid südamikke; spinatipundid, hapuoblikad, artišokikimbud, türgi ubade ja herneste kuhilad, õlega kokku seotud rooma salati virnad laulsid kogu rohelise värvigamma ulatuses kaunade lakiroheliste kuni lehtede tumeroheliseni (Zola 2002: 29).

Näeme, et Zola ei ürita turul leiduvat kuidagi tähenduslikku või hinnangulisse perspektiivi asetada. Erinevalt Balzaci püüust pansionihõngu tüüpilisust määratleda ei saa siin köögiviljade värvilisest paljususest ilma meele- 
valdsusesse kaldumata välja lugeda ühtki sotsioloogilis-ajaloolise tagapõhjaga heakskiitu või hukkamõistu turule ega selle territooriumil viibivatele inimestele. Loetletud üksikobjektid, antud juhul peamiselt köögiviljad, ei asetu mõne allegoorilise loo võimalikult ökonoomse edastuse teenistusse, vaid kipuvad otsustavatel hetkedel pihustuma hoopis puhtmeeleliste kvaliteetide määratuks ületulvaks - nii ei loetleta ühel hetkel enam isegi materiaalseid objekte, vaid võetakse (täienisti impressionistlikus vaimus!) vastu objektidest enestest otsekui autonoomset „õrna lillat”, „piimvalgega nüansseeritud roosat”, „kollasesse uppunud rohelisi” jne. ${ }^{10}$ Boriss Sutškov on tabavalt märkinud, et „Zola otsekui lahustab isiksuse selles keskkonnas, mille kõige vähemgi võnge või lainetus teda kaasa kisub" (Sutškov 1984: 176). Iga Zola lugeja teab, et need loetelud võivad väldata lehekülgi: esemete tohutu hulk, mis kirjaniku vaatele avaneb, kisub ta jutustamise lineaarse aja haardest lahti ning paiskab ühes temaga ka lugeja pikaks ajaks meeleliste kvaliteetide puhtasse impersonaalsesse („tähendusetusse"11) olevikku. Siin tulevad Kõivu inspireerivad sõnastused taas mängu: ka Zola köögiviljad „tulevad ise, nii nagu nad tulevad, vabad „meie” personaalsest interpreteeringust”, need "on kaotanud subjektiivse, või kui soovite, siis isikliku värvingu”, neilt on „lange[nud] ära kõik „minu isiklikud” atribuudid”, nende otsekui pidurdamatu tulva intensiivistamine märgib „süvenemises sündinud absoluutse meie ühiskogemust".

Stseenilisuse niisugune suhteline iseseisvumine, mida Zola puhul võib tuvastada ja piiritleda märksa selgemalt kui näiteks Balzaci või Flaubert'i puhul, märgib ühtlasi žanrilist kandumist realismist naturalismi. Ungari filosoof ja kirjandusteadlane György Lukács eristab täpselt analoogilistel alustel (realism kui jutustuse ja stseeni täpselt väljamõõdetud tasakaal vs. naturalism kui stseeni suhteliselt eneseküllasem autonoomia) realismi ja naturalismi kui kaht fundamentaalselt erinevat kirjutusviisi (jutustamine vs. kirjeldamine), millel on ühtlasi fundamentaalselt erinevad „ideoloogilised tagajärjed”. Essees „Jutustada või kirjeldada?” ütleb Lukács, et (naturalistlik) kirjeldamine, mida iseloomustab muuhulgas kõige (täienisti jamesonlik) taandamine olevikule ning „tegelaste alandamine elutute objektide tasandile” (Lukács 2005: 130, 133), ei ole suuteline dünaamiliselt kujutama inimesi ega ühiskonnaklasse tegevuses - kirjeldamine ei suuda haarata „elu sisemist poeesiat”, milleks Lukácsi jaoks on „inimvõitluse poeesia”, „ühiskondlike suhete turbulentne ja aktiivne poeesia" (Lukács 2005: 126). Viimasega saab hakkama üksnes realism (nt Dickens, Balzac, Tolstoi), kus kirjelduslik detail on veel andunult ja dünaamiliselt jutustamise teenistuses ega ole sestap kaotanud oma eepilist funktsiooni (vt Lukács 2005: 110-116, 127). Naturalistlik kirjeldamine, mis taandab kogemuse vaatluseks (Lukács 2005: 116-117) ning kõige oleva natüürmordilaadseks stoppkaadriks, ei ole oma olevikulise ajadimensiooni tõttu suuteline väljendama ega esile tõstma võitlevate klasside lootust (revolutsioonilisele) muutusele. Niisugusest vaatenurgast tuleks naturalismi mõtestada selle sõna „looduslikkusele” ja „loodusseisundile” osutavate semantiliste kon-

${ }^{10}$ Võiks vaielda, et Zola kirjeldus on sellegipoolest seostatav mõne tegelase (näljast nõrkenud põgeniku või akadeemiliselt haritud kunstniku?) vaatepunktiga. Ent käesoleva arutluse seisukohalt on määrav, et see on esitatud loetelulises, rangelt konstateerivas võtmes ning eraldubja iseseisvub oma kestvuse käigus poeetilise üksusena tegelaste personaalsetest vaatepunktidest.

${ }^{11}$ See tähendusetus põhistab muuhulgas näiteks koolilapse pragmaatilist kannatamatust „looga edasi minna”, otsekui üldkehtivat voli „kirjeldusi vahele jätta”. 
notatsioonide kaudu: „Söekaevurid” on naturalistlik teos seepärast, et kaevurite armetut elu on kirjeldatud kui väljapääsmatut ja muutusperspektiivita loodusseisundit - kui enesestmõistetavat naturaalset paratamatust, millesse nad on mõistetud (vt ka Sutškov 1984: 176). Sel moel kujutab naturalism endast realismi metodoloogilist ülepingutust, kus „stseen” ise on muutunud autonoomseks ehk „naturaalseks”. Ent see ei tähenda, et stseenilist valda realismis sugugi ei eksisteeriks: just naturalismi kaudu on võimalik realismi stseenilist komponenti kõige paremini tuvastada.

Arutluse selles punktis on võimalik formuleerida Jamesoni realismiteoreetilise ning Kõivu fenomenoloogilise lähenemise vaheline sugulus: personaalsete identiteetide ja saatuste režiimist autonoomselt eristuv stseeniline vald - teadvuse impersonaalne olevik - kujutab endast ühtlasi üht laadi kõivulikku „suhteliselt absoluutse meie või ühismina” valda, milles „langevad ära kõik „minu isiklikud” atribuudid”. Ning nüüd on võimalik välja pakkuda ka üks võimalus, miks realismi tunnetuslik objekt näib teiste kanooniliste vormide omadega võrreldes kuidagi intuitiivselt lihtsamini kokku lepitav, ühiselt paremini äratuntav. Potentsiaalselt erinevatele, personaalsetest identsustest kantud saatusejutustustele tagab siin usutavuse („ühise äratuntavuse”) personaalsest interpreteeringust vaba teadvuse impersonaalse oleviku „meie või ühismina sfäär”, mille „objektiivsust” ehk objektikesksust põhistab asjaolu, et „asjade isetulemise” tasandil oleme me sõltumata oma võimalikest erinevatest isiklikest atribuutidest ja saatustest kõik ühevõrra pelgalt teadvus el. Realismi (ja naturalismi) stseeniline vald markeerib s õ n a li s elt keelele ligipääsmatut ja nimetamisele vastu panevat „asjade isetulemise” afektiivset ühistasandit. ${ }^{12}$ Selle tasandi spetsiifiline sõnaline „sisu” või „fookusobjekt” võib (nagu varsti näeme) vastavalt žanrile, ajastule, kirjanduslikule konventsioonile jne erineda - ent sellegipoolest jõustab ja mõtestab selle tasandi „realistlikkust”, „objektiivsust” või „hõlpsat kokkulepitavust” hüpotees, et keele- või tähenduseelse pelga teadvusel-olu afektiivses vallas, absoluutse meie ühiskogemuses, „tulevad kokkulepped ise”.

\section{Subjektiivsuse lõhustumise kaks suunda: Zola ja Kõiv}

Kõivu ja Jamesoni sel moel sünteesides ei taha me sugugi väita, et XIX sajandi klassikalise realismi ja Kõivu kirjutamismetoodika eemaldumised personaalse identsuse subjektiivsest tasandist oleksid teineteisega kuidagi identsed või samasuunalised. Kõivu ja (näiteks) Zola „kalduvused stseeni poole” on täpselt vastupidise suunitlusega - impersonaalsed tasandid, kuhu kumbki välja jõuab, on ühisnimetajata. Sellegipoolest tundub meile nende juures sarnane

${ }^{12}$ Teadvustame, et kirjandust käsitledes tekib ületamatu vastuolu ühelt poolt asjade isetulemise ja puhta oleviku, logos'e voolu peatumise, aistingute ja afektide olla-laskmise, köögiviljade meres loksumise - ja teiselt poolt kirjanduse kui paratamatu tähistamise ja tähenduse tekitamise, sõnade kui märkide rittaseadmise, pideva tõlgendamise (turu kui ühiskonna peegelduse) vahel: et afekt „paneb keelele vastu”, aga kirjandus on pelgalt sõnakunst. Meie analüüs toimub sõnateose poeetiliste või narratiivsete üksuste ning nendevaheliste silmanähtavate erinevuste raames - „stseen” on selles mõttes paratamatult afektivalla sekundaarne tähistaja, aga siiski mitte afekt is e (üks asi on rääkida reaalsete organismide meelelistest, keele-eelsetest tajumustest ning teine asi on rääkida nende sõnalisest representatsioonist kirjanduses). Täname selle tähelepaneku eest Epp Annust. 
„subjektiivsuse lõhustumise mehhanism”, kuivõrd mõlemal juhul esitatakse arvestatav väljakutse personaalse identsuse narratiivsele tasandile. Kui realismis või naturalismis „hajub subjekt” ajutiselt tarbeesemete otsekui isetoimiva valla määratusse ülevoolu, mis peegeldab tagasi kapitalistliku turu diskursiivset hegemooniat (,ajastu poolt peale pandud malle”), siis Kõivul lahustub subjektiivsus puhtaks fenomenoloogiliseks reaalsuskogemuseks - ning selles liikumises võib näha pigem püüdu vabaneda igasugusest diskursiivsest hegemooniast.

Tunnistame, et turukirjelduse valik zolaliku naturalismi näiteks pole käesoleva arutluse raames sugugi juhuslik, sest XIX sajandi teises pooles, mil kapitalistlikud tootmis- ja tarbimissuhted olid juba piisava määrani intensiivistunud, kujutas just turustseen seda „reaalsuse” paradigmaatilist locus't, mis kõige paremini vastas keha impersonaalsele ja afektiivsele olevikule. (Mõningast mängulisust lubades võiks öelda, et turuplats markeerib nii metafoorselt kui ka sõna otseses mõttes „hõlpsa kokkulepitavuse kohta”, kus „asjad tulevad ise".) Siit ka esmajoones just materiaalsete üksikesemete, loo seisukohalt „luksuslike objektide” ja nende kvaliteetide määratu ületulv klassikalises mõttes realistlikes ja naturalistlikes kirjeldustes, mille eesmärk oli artikuleerida „kodanliku keha ajaloolist teket” (Jameson 2013: 42). Niivõrd, kuivõrd võib öelda, et siinkohal vaadeldava ajaperioodiga samalaadsed (ehkki nüüdseks ilmselt veelgi intensiivistunud ning selle käigus teisenenud) tootmis- ja tarbimissuhted domineerivad ühiskonnas tänapäevani, ei kao kirjandusest kusagile ka XIX sajandi klassikalisele realismile või naturalismile tunnusliku, materiaalsetele objektidele ja tarbeesemetele ning nende (iseseisvunud) omadustele keskenduva (turu)stseeni aktuaalsus, usutavus ja „objektiivsus”. Tunnuslikemaiks näideteks võiksid olla Don DeLillo „Valge müra” (White Noise”, 1985), Bret Easton Ellise „Ameerika psühhopaat” („American Psycho”, 1991) ja William Gibsoni „Mustrituvastus” („Pattern Recognition”, 2003).

Nagu mainisime, laguneb Kõivul personaalse identsuse subjektiivne tasand võrreldes naturalistliku (turu)stseeniga täpselt vastupidises suunas. Tema proosastiili - või ehk talle iseloomulikku suveräänset keeldumist millestki sellisest nagu stiil - iseloomustab peamiselt teksti pidev ja äärmiselt detailne fenomenoloogiline tähelepanu ümbritsevale maailmale ja järjekindel loobumine igasugusest tavamõistes diskursiivsest, seletavast toonist (Pilv 2004: 12-13, 2005: 668-669). Tema tekstidest eksperimentaalsemate, eriti romaanide „Aken” (1996) ja „Päev” (2004) puhul on võimalik jälgida, kuidas see ainitine tekstuaalne tähelepanu liigub aeg-ajalt jutustuse rahulikust edasikandmisest kõivuliku puhta stseeni registrisse, milles lugeja avastab end täielikult erinevate mäluliste fragmentide (kas jutustaja mäletab mingit sündmust korrektselt?), modaalsuste (kui kindel mingi sündmus, otsus, paratamatus üldse on/oli?) ja lähikirjelduste autonoomsest tsoonist. Kõige külluslikumalt näiteid sellistest üleminekutest pakub ilmselt romaan „Päev”. Näiteks VII peatükk keskendub peamiselt hämarale ülekuulamisepisoodile ühes maa-aluses toas, kuhu minajutustaja jõuab ja esialgu oma sealviibimise kohta ratsionaalselt arutleb: „Kummaline asi - kas on mu viibimisel siin, selles toas; siin riiulite vahel laua juures istumisel, tee rüüpamisel mingi eesmärk, mõni otstarve, või lihtsalt, tulen sisse, ütlen tere, võtan istet - palun istuge, soovite teed, kohvi... ja edasi? Ta seisab ja vaatab mind" (Kõiv 2004: 117). Eelneval leheküljel on vihjatud, et peale (mina)jutustaja viibib toas veel kaks 
meest, kellest üks seisab raamaturiiulite kõrval ja teine istub laua taga. Kohe oma sisemonoloogis esitatud küsimuse järel kirjeldabki autor silmside tekkimist istuva mehega ning alustab sellega tervet iseseisvat stseenilist kirjeldust:

Sel hetkel on tasakaal oma labiilsuse ülimas seisundis, kuid ikkagi seisundis, s.t tasakaal püsib - ta vaatab mind, õieti mu pilku; tasakaal, mis toetub pilkude üksteise otsa kuhjatud klotsidest, on oma ülima, veel kujuteldava astmeni labiilne; teravate servadega - ei, isegi mitte seda, nurkadega - üksühele toetuvate klotside püramiid kukub, ta ei saa jääda püsima: tasakaalust väljavajumise lõpmatuseni venitatud hetk. Ainult sellepärast püsivad pilgud oma vastastikku ehitatud tornil, püsib raamatulugeja avause kohal, õlg peaaegu puutumas seina - aga veel mitte - jalg peaaegu astumas kuristikku - aga veel mitte -, pilk libisemas raamatult põrandale, haaramaks sügavikku, nagu ta on - aga veel mitte, veel... (Kõiv 2004: 117).

Kõivu proosakeelt iseloomustab selliste episoodide puhanguline esiletõus jutustuse vahelt, ehkki neid on „tavanarratiivist” märksa keerulisem eristada kui realistlikku lugu seda tasakaalustavatest stseenidest. (Õigupoolest jõuavad paljud Kõivu tekstid „tavanarratiivi” tasemele üpris harva, heaks näiteks on jutustus „Õun”, kus unenäo ja reaalsuse vaheline modaalne segadus kujutab endast pigem kogu teksti „tuumtasandit”.) Nii kannab ka eelnev näitelõik teatud määral edasi loo sündmusi, kuid sedavõrd atomaarsel viisil, et lahustab kirjeldatud olukorra (pilgu püsimine, teise mehe õla liikumine) lõpuks impersonaalsesse puhtaistingulisse igavesse olevikku: subjektiivse narratiivse tasandi pilk, mis vaatab „mu pilku”, lahustub mina põhjani süvenemise tulemusel „lõpmatuseni venitatud hetkeks”, kus „üksteise otsa kuhjatud klotside”, „üksühele toetuvate klotside püramiidi”, „pilkude vastastikku ehitatud torni” kukkumine on igaveses viibimises (,aga veel mitte”). Süvenemine pilkude kohtumisse viib siingi „meie” või „ühismina” puhtfenomenoloogilisele tasandile, mida markeerib inimeste võrdne teadvusel-olu ning „asjade isetulek”. Sestap kutsuksime Kõivu niisugust kirjutusviisi tinglikult fenomenoloogiliseks realismiks - barthes'ilikku „reaalse tasandit” ja Jamesoni stseenilise oleviku valda esindab siin sõnaline püüd läheneda puhtfenomenoloogilisele tegelikkuse kogemusele enesele.

\section{Väljajuhatus: realism üle realismi piiride}

Kõige selle põhjal saab teha kaks lisajäreldust. Üks neist puudutab stseenilist olevikku kui kirjandusliku realismi iselaadse usutavuse üht olulist lätet, teine aga stseenilisel olevikul põhineva realistliku tõepära elujõudu klassikalisele realismile järgnenud modernistlikes kirjandusvormides.

Essees „Tõenäolisus ja motivatsioon” käsitleb Gérard Genette tõenäolisust kui narratiivi meelevaldsuse parajat määra - nende sündmuste valikute laiust ja ahtust, kuhu lugu u suta valt pöörata võib, ilma et see meelevaldsena mõjuks. Genette, kes sellest rakursist käsitleb kõigepealt XVII sajandi prantsuse klassikalise ajastu kirjanduslikke tekste, sisustab tõenäolisuse mõiste „vastavuse, sobivuse või kombepuhtusega" (Genette 2011: 181) - mitte sellega, kuidas „asjad on”, vaid sellega, kuidas need „peaksid olema”, „olema- 
pidavaga" (Genette 2011: 180). Tiina Kirss märgib tabavalt, et niisuguses režiimis määratleb tõenäolist narratiivi "esmajärjekorras kujutatud tegevuste vastavus maksiimidele, mida adressaadiks olev lugemispublik õigeks peab" (Kirss 2011: 203). Nii polevat Pierre Corneille' „Cidi” (1637) toonaste kriitikute arvates „teps mitte tõenäoline, et autundega tütarlaps naituks oma isa mõrtsukaga" (viidatud Genette 2011: 179-180) - selline asi saavat usutavalt juhtuda üksnes tõsiloos. Kui „klassikalisel ajastul” defineeris tõenäosust niisiis narratiivi vastavus „avalikus arvamuses käibel olevate juhtmõtete (maksiimide) kogumiga” ning „vaikiv nõusolek kombepuhtuse normidega” (Kirss 2011: 203), ${ }^{13}$ siis edasi täheldab Genette just Balzaci näitel, kuidas XIX sajandil ilmub välja „poolriukaliku narratiivi tüüp” (Genette 2011: 184), mis teeskleb „igas töös oma ürituse huvides kunstlikku tõenäolisust” (Genette 2011: 185). Selle kunstliku tõenäolisuse markeriteks on ohtrad pedagoogilised klauslid ja seletused, mis „on jutustuse teenistuses, andes (eriti mittepariislasest) lugejale edasi mitmesuguseid argitarkusi talle võõrast provintsielust" (Kirss 2011: 205). Näiteks: „„Ja nimelt sellepärast...”; „Järgneva mõistmiseks on ehk tarvilikud mõned selgitused...”; „See asjaolu nõuab selgitamist...”; „Siia on tarvilik lisada mõned selgitused...”; „Selle loo mõistmiseks...” jne” (Genette 2011: 185). Kirss üldistab õigustatult, et sellise võttega loob Balzac „oma romaanides süsteemsusele pürgiva „provintsielu etnograafia” ehk provintsliku tõenäolisusesüsteemi” (Kirss 2011: 205).

Käesolevas arutluses läbi viidud Kõivu ja Jamesoni sünteesi põhjal tahaksime nende kahe (kahtlemata ajaloolises järgnevuses välja kujunenud) tõenäolisuse-tüübi kõrvale asetada veel kolmanda, mis ilmneb kõige paremini realistliku stseenilisuse naturalistliku süvenemise juures ning märgib barthes'ilikult öeldes „klassikalisele vastanduva realistliku tõepärasuse” sündi. Kutsuksime seda tõenäolisuse-tüüpi stseeniliseks tõenäolisuseks, kuivõrd selle allikaks on narratiiviga lõdvalt või üldse mitte seonduvad elemendid - elemendid, mis „pole jutustuse teenistuses”, ent mis teose usutavuse tagamiseks on sellegipoolest hädavajalikud. ${ }^{14}$ Barthes'i näitest tuntud, jutustuse suhtes luksuslik Flaubert'i baromeeter, aga ka Zola turustseeni värvideks ja valgusmänguks pihustuvad köögiviljad - niisuguse tõenäolisuse lätteks pole mitte vastavus sellega, mis on looliselt sünnis või kombekohane, vaid sõnade vastavus pelga aistingulise tegelikkusega, lineaarse loo suhtes selgelt iseseisva kehade impersonaalse ja afektiivse olevikuga (olgu seda tegelikkust või olevikku tähistavad loetelud lõppkokkuvõttes kui tahes „diskursiivsed”). Selles tõenäolisuse režiimis osutatakse tekstivälisele tegelikkusele kvalitatiivselt teistsugusel moel - siin ehitatakse mimeetilist ruumi ilma kindlatele narratiivsetele subjektipositsioonidele toetumata või pigem neid positsioone järjekindlalt lagundades ja lahustades. Niimoodi loodud stseenitasand on võimalikult vaba Kõivu kirjeldatud „ „mina” enda poolt suvaliselt juhitud ja indutseeritud seikadest", sest moodustub ainuüksi impersonaalsetest singulaarsustest, mille ainus omadus ja funktsioon ongi nüüd rangelt võttes (ühine) äratuntavus ja vahetu kohalolu. Selline on meie esimene lisajäreldus.

${ }^{13}$ Selle ajastu teoste esteetilisi proportsioone kirjeldab Rancière’i „kunstide representatiivne režiim" - vt allmärkust 7.

${ }^{14}$ Seda isegi siis, kui ka see tõenäolisuse süsteem oli esiotsa „loodud” - nii Flaubert'il kui ka Zolal olid kirjutamiseks selgelt sõnastatud metodoloogilised printsiibid. 
Viimaks on võimalik näidata, kuidas realismis ja naturalismis esilduv stseenilisus võib osutuda sõnade ja asjade vahelise vastavussuhte ankrupunktiks ka neile järgnenud modernistlike kirjandusvormide juures. Fredric Jameson täheldab uurimuses „Realismi antinoomiad”, et „realism on [saatuse ja igavese oleviku] vahelise pinge tulemus; kui pinge ühe kasuks ära lahendada, laguneb ka realism ise" (Jameson 2013: 12). Nii märgib modernistlike kirjandusvormide teke juba stseeni märksa täielikumat hegemooniat jutustuse üle - ning sõnad ei otsi neis vastavust esmajoones mitte (näiteks) välise materiaalse reaalsuse või kodanliku igapäevaeluga, vaid stseeniliste nähtustega, mis osutavad keelelisele väljendusele märksa suuremat vastupanu. Keskseks näiteks võiks siinkohal olla sürrealistlik automaatkirjutus kui püüd väljendada sõnas mitteteadvuse peaaegu määratlematut liiasust teadvuse identsuse üle - viia sõnad vastavusse teadvustamatuga. Jean-François Lyotard on käesoleva arutlusega vägagi kongeniaalsel viisil kirjeldanud ka näiteks Prousti ja Joyce'i suurromaane:

Nii Prousti kui ka Joyce'i looming vihjab millelegi, mis ei lase end kohalolevaks teha. [---] Prousti puhul on aga vihjamise hind see, et kaduma läheb teadvuse identsus - see langeb liiga paljude aegade ohvriks. Joyce'il omakorda kaob vihjamise hinnana kirjutuse identsus - liiga paljude raamatute või kirjanduse ohvrina. Proust vihjab kujutamatule puutumatu süntaksi ja sõnavaraga keele abil ning kirjutuse abil, mis paljude oma tegurite poolest kuulub veel romaanile omase jutustamise žanri. Kirjanduslik institutsioon, mille Proust päris Balzacilt või Flaubert'ilt, on muidugi pahupidi pööratud - selles mõttes, et kangelane pole enam tegelane, vaid ajas kulgev teadvus.... (Lyotard 2014: 39-40).

Ka siin helisevad otsekui iseeneslikult kaasa Kõivu inspireerivad sõnastused - kas ei kujuta sürrealistlik automaatkirjutus või Prousti romaanis kesksele kohale asetuv tahtmatu meenumise mehhanism endast süvenemises sündinud asjade isetulemist par excellence? Tulemuseks pole loomulikult konventsionaalne realism, aga sõnade ja asjade vaheline vastavussuhe - kirjutusviis - jääb sellegipoolest realistlikuks laiemas mõttes:

Sellest vaatenurgast on võimalik näha, kuidas kirjanikke, kellest mõeldakse kui antirealistlikest modernistidest, saab kaasata uute realismide ajalukku. [---] Reaalsus paigutatakse ümber - viiakse „sissepoole” -, kuid tegelikkuse või „elu” õige kujutamine jääb keskseks eesmärgiks täpselt samamoodi nagu klassikaliste realistlike kirjanike puhul (Bowlby 2007: xvi).

Samas vaimus võiks juba päris üldisel tasandil oletada, et Kafka jaoks paigutub tegelikkus ümber näiteks bürokraatlike süsteemide liiasusse üksikindiviidi üle ning postmodernistlikus paradigmas näiteks hüperreaalse või simulatsioonilise liiasusse tegelikkuse enese üle. Edasine uurimine võiks käsitleda stseenilise oleviku avaldumist näiteks Georges Pereci peaaegu nullstiililistes loeteludes või Alain Robbe-Grillet' püüdlustes objekti võimalikult mikroskoopiliselt ja täpselt kirjeldada. Või mõnes uue sajandi uussiiras „nüüdisrealistlikus" teoses, kus mõnevõrra teisenenud vormis võib taas täheldada klassikalisele realismile sarnast jutustuse ja stseeni vahelist tasakaalu. 
Sellest stseenilisel olevikul põhineva realistliku tõepära perspektiivist loovad uued realismid uusi vaateid tegelikkusele (vt ka Robbe-Grillet 1996: 157-168). Nii kätkevad ka kõikvõimalikud klassikalisele realismile järgnenud kirjandusvoolud endas sõnade ja asjade vahelist realistlikku vastavust - isegi kui need „asjad” pole enam osakesed meile enesestmõistetavast välisest või eeleksisteerivast materiaalsest tegelikkusest, vaid pärinevad mõnest raskemini tuvastatavast vallast või luuakse lausumise käigus.

\section{Kirjandus}

B alz a c, Honoré de 2004. Isa Goriot. Tlk Bernhard Linde. Tallinn: Avita.

B a r th e s, Roland 2002. Reaalse efekt. Tlk Indrek Koff. - R. Barthes, Autori surm.

Valik kirjandusteoreetilisi esseid. Tallinn: Varrak, lk 105-116.

Bea um ont, Matthew 2007. Introduction: Reclaiming Realism. - Adventures in

Realism. Toim Matthew Beaumont. London: Wiley, lk 1-12.

B ow lby, Rachel 2007. Foreword. - Adventures in Realism. Toim Matthew Beaumont. London: Wiley, lk xi-xviii.

Dentith, Simon 2007. Realist Synthesis in the Nineteenth-Century Novel: "That unity which lies in the selection of our keenest consciousness." - Adventures in Realism. Toim Matthew Beaumont. London: Wiley, lk 33-49.

Fla u b e rt, Gustave 1995. Üks lihtne hing. - Kolm juttu. Püha Antoniuse kiusamine. Tlk Tatjana Hallap, Tiiu Kaldma, Anu Lõun. Tallinn: Perioodika.

Genette, Gérard 2011. Tõenäolisus ja motivatsioon. Tlk Anti Saar. - Methis. Studia Humaniora Estonica, nr 8, lk 179-199.

J ak o bs o n, Roman 2014. Realismist kunstis. - Kirjandus kui selline. Valik vene vormikoolkonna tekste. Koost ja toim Märt Väljataga. Tallinn: TLÜ kirjastus.

J a m e s o n, Fredric 2013. Antinomies of Realism. London-New York: Verso.

Kangro, Maarja 2012. Jacques Rancière'i poliitiline esteetika. - Vikerkaar, nr 4-5, lk 128-141.

Kant, Immanuel 2000. Critique of the Power of Judgement. The Cambridge Edition of the Works of Immanuel Kant. Tlk ja toim Paul Guyer. New York: Cambridge University Press.

Kirs s, Tiina 2011. Kultuuritõlge ruudus: Gérard Genette’i „Tõenäolisus ja motivatsioon”. - Methis. Studia humaniora Estonica, nr 8, lk 200-207.

Kõ iv, Madis 2004. Päev. Tartu: Akkon.

Kõ i v, Madis 2007. Subjektiivsuse objektiivsusest. - Looming, nr 8, lk 1256-1257.

Levine, George 2007. Literary Realism Reconsidered: „The World in its length and breadth”. - Adventures in Realism. Toim Matthew Beaumont. London: Wiley, lk 13-32.

Lu ká cs, Georg 2005. Narrate or Describe? - Writer and Critic. Tlk Arthur Kahn. Lincoln: An Authors Guild Bacprint.com Edition, lk 110-148.

L u ká cs, György 2006. The Meaning of Contemporary Realism. Tlk John ja Necke Mander. Monmouth, UK: Merlin.

Ly ot a rd, Jean-François 2014. Postmodernsusest lastele. Kirju aastatest 19821985. Tlk Mirjam Lepikult. Tallinn: Tallinna Ülikooli Kirjastus.

Pilv, Aare 2004. Madis Kõiv. Writer to an ideal reader. - Estonian Literary Magazine, $\mathrm{nr}$ 19, lk 10-16. 
Pilv, Aare 2005. Järelsõna. - M. Kõiv, Luhta-minek. (Eesti mõttelugu 61.) Tartu: Ilmamaa, lk 665-671.

R a n c i è r e, Jacques 2004. The Politics of Aesthetics. Tlk Gabriel Rockhill. LondonNew York: Continuum.

R a n cièr e, Jacques 2011. The Politics of Literature. Tlk Julie Rose. Cambridge: Polity.

Robbe-Grillet, Alain 1996. For a New Novel. Essays on Fiction. Tlk Richard Howard. Evanston, Illinois: Northwestern University Press.

Räh e s o o, Jaak 1999. Madis Kõivu näidenditest. - Looming, nr 12, lk 1861-1874.

R äh e s o o, Jaak 2000. Madis Kõivu näidenditest II. - Looming, nr 9, lk 1363-1382.

Sutško v, Boriss 1984. Realism läbi aegade. Tlk Georg Meri. Tallinn: Eesti Raamat.

Z ol a, Émile 2002. Pariisi kõht. Tlk Tatjana Hallap. Tallinn: Perioodika.

Undusk, Jaan 1986. Friedebert Tuglase „realism” ja sajandivahetuse kultuur. Tallinn: Eesti NSV Teaduste Akadeemia.

Wellek, René 1976. The Concept of Realism in Literary Scholarship. - Concepts of Criticism. New Haven-London: Yale University Press.

\section{On the autonomy of bodily present in the aesthetics of literary realism}

Keywords: realism, naturalism, descriptions, affect, objectivity

The article explores one possible source of the verisimilitude of literary realism - its prominent detailed descriptions of material and social reality. Our aim is to relate this poetically autonomous descriptive faculty to the alleged representational objectivity of literary realism, and explain how descriptions function as a source of realist verisimilitude from a philosophical as well as poetic point of view. We use Madis Kõiv's phenomenological explanation of the relationship between subjectivity and objectivity from his little-known text „On the Objectivity of Subjectivity” to see how it reflects upon Fredric Jameson's recent elaboration of literary realism as a poetic balance between the distinct faculties of narrative and scene, emotion and affect, personal fate and impersonal bodily present. We show how Kõiv's thoughts on the objectivity of phenomenological existence supplement Jameson's claim that realist descriptions, as autonomous poetic units, signify the impersonal affective present common to all bodily experience. We analyze the poetics of literary descriptions by Balzac, Flaubert, and Zola to trace the gradual historical autonomy of affective bodily present from realism to naturalism and beyond. Madis Kõiv's own work is presented in this context as an example of Estonian literary modernism.

Indrek Ojam (b. 1988), MA, University of Tartu, doctoral student at the Department of Literature and Theatre Studies, indrekojam@gmail.com

Jaak Tomberg (b. 1980), PhD, University of Tartu, researcher at the Department of Literature and Theatre Studies, jaak.tomberg@gmail.com 